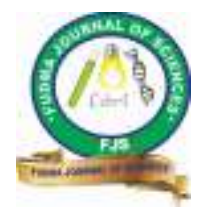

FUDMA Journal of Sciences (FJS)

ISSN online: $2616-1370$

ISSN print: 2645 - 2944

Vol. 4 No. 3, September, 2020, pp $496-504$

DOI: https://doi.org/10.33003/fjs-2020-0403-396

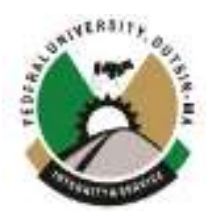

\title{
DISTRIBUTION AND POPULATION DENSITIES OF PLANT-PARASITIC NEMATODES ASSOCIATED WITH GINGER (ZINGIBER OFFICINALE) IN KADUNA STATE, NIGERIA
}

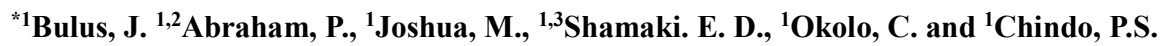 \\ ${ }^{1}$ Department of Crop Protection, Faculty of Agriculture/Institute for Agricultural Research, Ahmadu Bello University Zaria, \\ Kaduna State, Nigeria \\ ${ }^{2}$ Department of Horticulture, Federal College of Horticulture Dadin Kowa, Gombe State, Nigeria \\ ${ }^{3}$ Federal College of Freshwater Fisheries Technology, New-Bussa, Niger State, Nigeria \\ Corresponding Author's email: bjulius2012@gmail.com, +2348062517626
}

\begin{abstract}
Ginger (Zingiber officinale) is an important cash crop in Nigeria. In spite of the economic importance of plant-parasitic nematodes reported on ginger, little or no information is available as regards plant-parasitic nematodes diversity and abundance on ginger in Nigeria. This work was conducted in 2018 to identify plantparasitic nematodes associated with ginger in Kaduna state and to determine their population densities. Three Local Government Areas (LGA) were visited and between 12 to 16 ginger farms were sampled per LGA. A total of 42 soil samples was collected at a depth of $0-30 \mathrm{~cm}$ of the plant rhizosphere. Plant-parasitic nematodes were extracted from the soil using modified sieving and decanting method. Identification to genera level was done using identification keys viewing with dissecting microscope at X40 magnification. Nineteen (19) genera of plant-parasitic nematodes were identified, with 12 genera occurring in all LGA(s). Scutellonema (113.33), Meloidogyne (110), and Pratylenchus (93.33) were the most abundant per $100 \mathrm{ml}$ of soil when locations are combined. Plant-parasitic nematodes population average was $870-950$ per $100 \mathrm{ml}$ of soil. All locations showed a high percentage similarity of plant-parasitic nematodes diversity and were statistically similar. This high diversity and population abundance can be among the reasons for the low productivity of ginger in Nigeria. It is therefore important to educate farmers on the economic importance of plant-parasitic nematodes on ginger and its management. Further research using the most occurring genera to establish the threshold population densities capable of causing economic yield loss needs to be conducted.
\end{abstract}

Keywords: Plant-parasitic nematodes, survey, ginger, genera, rhizosphere.

\section{INTRODUCTION}

Ginger (Zingiber officinale Roscoe) is among the earliest known rhizomatous spices valued the world over (Sawa, 2017). Though the entire plant is refreshingly aromatic, the underground rhizome is the most useful part of this plant. The rhizome is valued as an important raw material in pharmaceutical, confectionary and beverage industries (Sawa, 2017: Singh and Singh-Dhillon 2015). It is a perennial herb belonging to the family, Zingiberaceae but also grown as annual (Fikre and Kifle, 2013). The crop is native to tropical rainforest of Asia. Today, it is grown in over 30 countries of the world (FAOSTAT, 2017) mainly as a cash crop (Mazza, 2015). In Nigeria, ginger is an important cash crop, and Nigeria is among the leading world producers (Ojiako et al., 2007) and exporters of this crop (Asumugha, 2002). Research has shown increase in ginger production in Nigeria in the past years (FAO, 2009). Kaduna state remains the country's leading producer where the crop was known to be introduced first in 1927. The crop is mainly grown by predominantly peasant farmers as a cash crop, in places like Jaba, Jama'a, Kachia and Kagarko local Government areas of the state (Nmadu and Marcus, 2013; USAID-NEXTT, 2017). In recent times however, cultivation of ginger has now spread to all the country's geographical zones (Duniya, 2003; Bernard, 2008).

In spite the benefits of this crop and it prospect in Nigeria as an export crop, the production of ginger is significantly affected by biotic and abiotic factors (Abraham et al., 2020). Among the biotic factors, are nematodes (Paret et al., 2010; Sharma et al., 2010). Nematodes feeds on the rhizomes, roots and base of the pseudo stems. It causes swellings or knots, rot of root, root cracking and deformation etc. In the above ground parts, it causes stunting of the plant, chlorosis and marginal necrosis of leaves. It also causes reduced vigor and tillering and dark brown necrotic lesion. These symptoms are caused not only by a single nematode species but different species of nematodes in a complex. Nematodes also predisposes the rhizome to fungal and bacterial attack through their entry points on the rhizome. As a result of these, about $74 \%$ weight of the rhizome can be loss (Meenu and Jeba, 2019). However, research recommendations in Nigeria in the area of pests and diseases of ginger are minimal and reports of pest damage on the crop especially of nematodes related are scanty (Ibedu et al., 1990). The objective of this study therefore was to identify the diversity and determine the plant parasitic nematodes population abundance in soils under ginger cultivation in Kaduna state.

\section{MATERIALS AND METHODS}

Surveyed locations

Survey was conducted in 2018 rainy season to determine the occurrence and distribution of plant parasitic nematodes associated with ginger (Zingiber officinale) in Kaduna State and to determine their population densities. Three Local 
Government Areas [LGAs] i.e. Jaba, Kachia and Kagarko (Fig. 1) known to be the leading producers of ginger in the state were selected for the survey. In each LGA, between 12 to 16 farms were selected for the sample collection with the assistance of Agricultural Development Project (ADP) management staff members who aided our linking up with the farmers' for easy access to the farms.

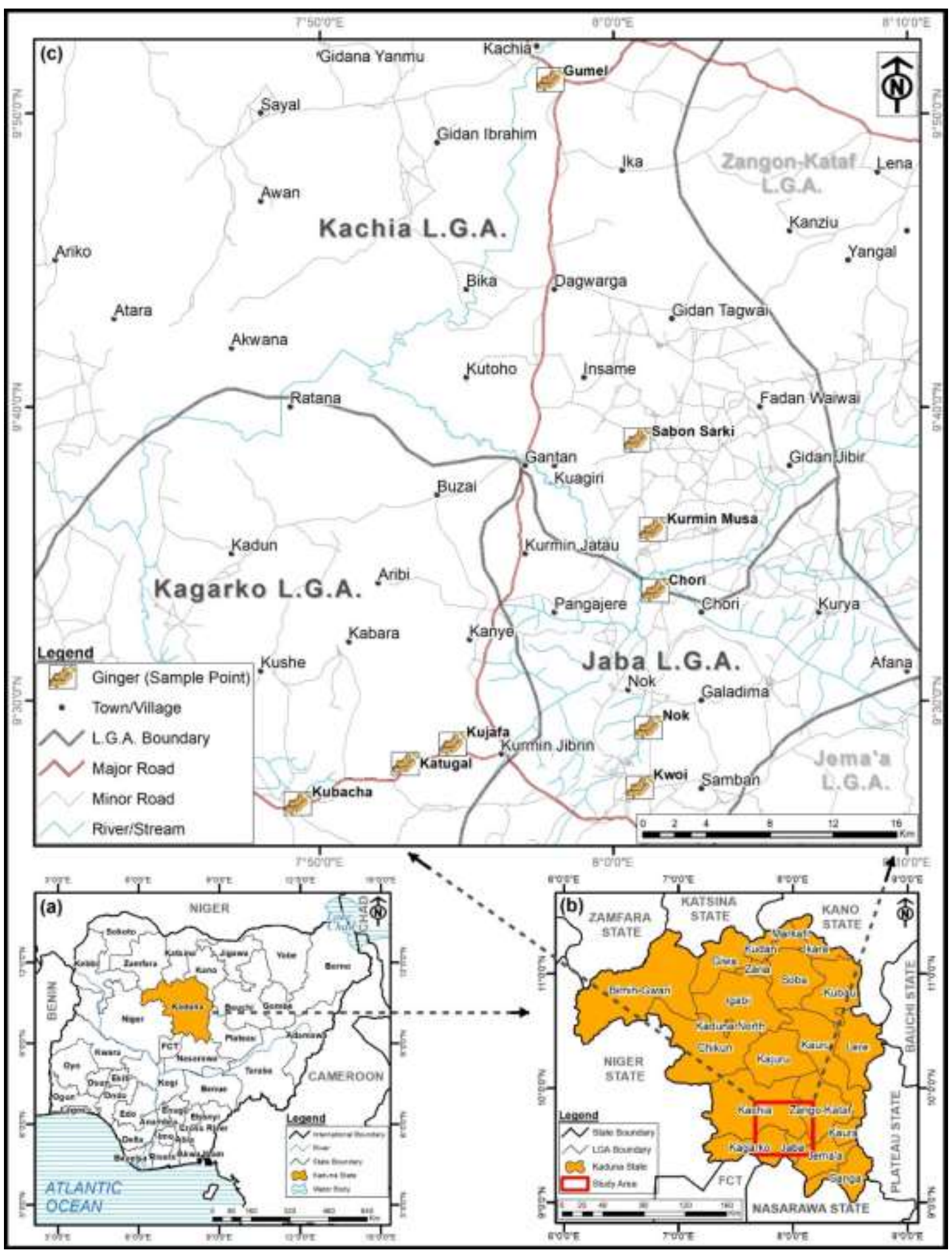

Figure 1: (a) Nigeria showing Kaduna State, (b) Kaduna State showing Kachia, Kagarko and Jaba L.G.As. (Study Area), (c) Study Area showing Sample Points. Source: Fieldwork/Map Gallery, Geography Department, ABU Zaria 


\section{Soil sample collection}

Sample collected was basically soil from the rhizosphere of the plants with the aid of a soil auger. This was collected at a depth of $0-30 \mathrm{~cm}$ and within a radius of $25 \mathrm{~cm}$ from the base of the plants. Between 12 to 16 selected farms were surveyed in each LGA. Each of the selected farms, ranges from 0.5 to 1 hectre and 35 to 50 soil cores were randomly collected in a zigzag pattern in each farm, bulked per farm to form a composite sample weighing about 1.5 to $2.5 \mathrm{~kg}$. Each of the composite sample was packaged in a polyethylene bag, properly labelled and then transported to Ahmadu Bello University Zaria Nematology laboratory for nematode extraction.

\section{Extraction of nematodes from the Soil Samples}

Extraction of the plant-parasitic nematodes from the soil samples was done using the modified sieving and decanting techniques as described by Coyne et al. (2007). One hundred millilitres $(100 \mathrm{ml})$ of soil was collected from each of the composite soil sample and poured gently into a fifteen-litre plastic bucket containing five litres of water. These was stirred Data analysis

The distribution and population density of nematodes were calculated using the formulae of Norton (1989) but with modifications on the percentage similarity as follows:

$$
\begin{gathered}
\text { Absolute density }(\%)=\frac{\text { Number of nematodes in all the samples }}{\text { Total number of samples collected }} \times 100 \\
\text { Absolute Frequency }(\%)=\frac{\text { Number of samples containing nematodes }}{\text { Total number of samples collected }} \times 100
\end{gathered}
$$

$$
\text { Percentage Similarity }(\%)=\frac{\mathrm{KS}}{\mathrm{a}+\mathrm{b}+\mathrm{c}+\cdots} \times 100
$$

Where:

$\mathrm{K}=$ Number of comparing locations;

$\mathrm{S}=$ Number of nematode genera that the comparing locations have in common;

$\mathrm{a}, \mathrm{b}, \mathrm{c},=$ Number of nematode genera in each of the comparing locations.

\section{RESULTS AND DISCUSSIONS}

The result of this study showed a high diversity of plantparasitic nematodes associated with ginger in Kaduna state of Nigeria. A total of 19 genera of plant-parasitic nematodes were identified to be associated with ginger in Kaduna state (Table 1) with most of the genera in the order Tylenchida which is the only order in class Chromadoria mostly harbouring the highest diverse plant-parasitic nematodes. However, variation occurs in genera diversity between locations. Kachia recorded 18 genera while Jaba and Kagarko L.G.A(s) recorded 14 genera each (Table 2). This agrees with the works of Thakur and Shamar (2015) who recorded 15 genera of plant parasitic nematodes to be associated with ginger in India. The increase number of genera from this work may be influenced by location, varietal differences and management practices. Twelve (12) genera were identified to occur in all locations (Aphelenchus, Aphelenchoides, Helicotylenchus, Hemicycliophora, Longidorus, Meloidogyne, Pratylenchus, Rotylenchus, Scutellonema, Tylenchorhynchus, Tylenchus and Xiphinema) which may define their level of importance as relate to ginger cultivation. Earlier report showed 9 genera identified to be important in ginger cultivation (Thakur and Shama, 2015). This variation may also be due to management practice, varietal differences and location. Among the 12 listed nematodes are those classified as threat to world agricultural production causing an estimated yield loss of 80-118 billion dollars annually, these include: Meloidogyne, Pratylenchus, Xiphinema and Longidorus (Nicol et al., 2011; Sasser and Freckman, 1987; Hodda et al., 2012) 
Table 1. Generalized classification of the plant-parasitic nematodes identified to be associated with ginger in Kaduna state

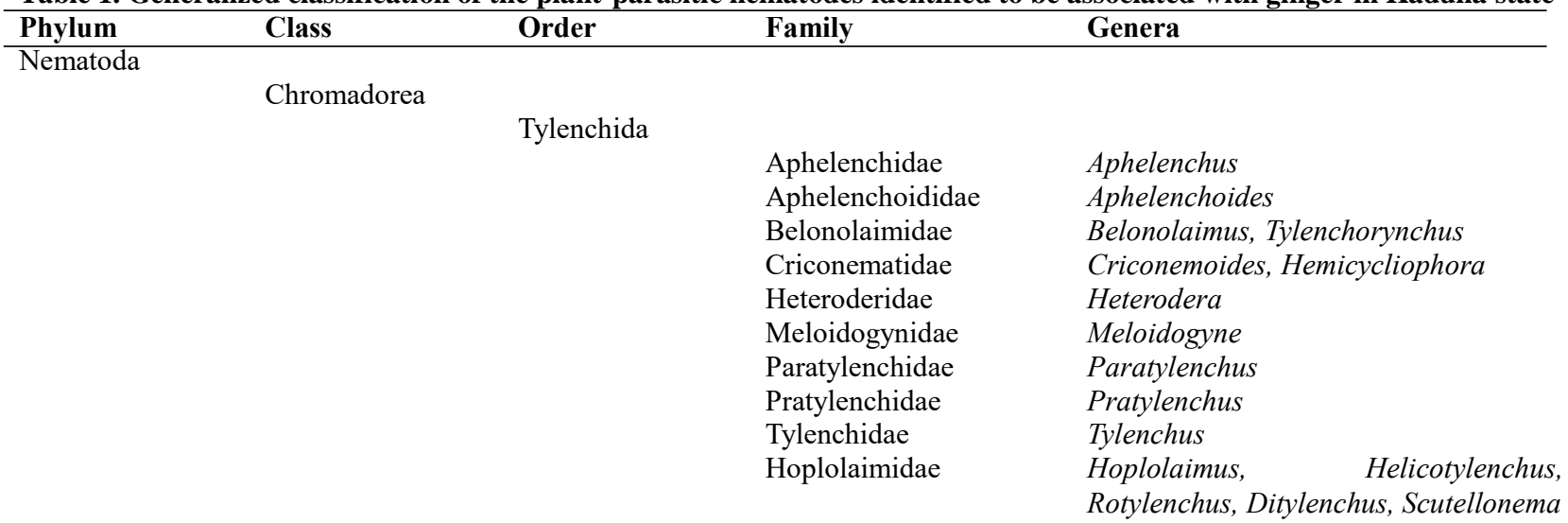

Anoplea

Dorylaimida

Longidoridae Longidorus, Xiphinema

Triplonchida

Trichodoridae Trichodoru

Table 2: Abundance and occurrence of Plant parasitic nematodes associated with ginger in Jaba, Kachia and Kagarko Local Government Areas of Kaduna State, during the field survey

\begin{tabular}{|c|c|c|c|}
\hline \multirow[t]{2}{*}{ Nematode Genera } & \multicolumn{3}{|c|}{ Location } \\
\hline & Jaba & Kachia & Kagarko \\
\hline Aphelenchus sp. & + & + & + \\
\hline Aphelenchoides sp. & + & + & + \\
\hline Belenolaimus sp. & - & + & + \\
\hline Criconemoides sp & - & + & + \\
\hline Ditylenchus sp. & - & + & - \\
\hline Helicotylenchus sp & + & + & + \\
\hline Hemicycliophora sp. & + & + & + \\
\hline Heterodera sp. & - & + & - \\
\hline Hoplolaimus sp & - & + & - \\
\hline Longidorus sp. & + & + & + \\
\hline Meloidogyne sp & + & + & + \\
\hline Paratylenchus sp & + & + & - \\
\hline Pratylenchus sp & + & + & + \\
\hline Rotylenchulus sp & + & + & + \\
\hline Scutelonema sp & + & + & + \\
\hline Tylenchorhynchus sp. & + & + & + \\
\hline Tylenchus sp. & + & + & + \\
\hline Trichodorus sp. & + & - & - \\
\hline Xiphinema $\mathrm{sp}$ & + & + & + \\
\hline Total & 14 & 18 & 14 \\
\hline
\end{tabular}

$+=$ detected, - = not detected

Population densities (average) was observed to be relatively high for most of the genera. In Jaba LGA Scutellonema (150) had the highest density per $100 \mathrm{ml}$ of soil followed by Aphelenchus (120) Rotylenchus (110) and Meloidogyne species (100). While Belenolaimus, Criconemoides, Ditylenchus, Hoplolaimus and Heterodera did not record any number (Table 3). In Kachia LGA also Meloidogyne (130) had the highest number, followed by Rotylenchus (100) and Hoplolaimus (80) while Trichodoru had zero (Table 3). Kagarko LGA shows Pratylenchus (170) recording the highest number followed by Scutellonema (150) and Meloidogyne (100) (Table 3). When all locations are combined, Scutellonema (113.33) recorded the highest density followed by Meloidogyne (110) and Pratylenchus (93.33). Earlier reports by Kaur and Sharma (1988), Makhnotra (1994) and Thakur and Shamar (2015) reported the Pratylenchus and Meloidgyne to be highest in terms of frequency of occurrence and population densities in fields under ginger cultivation. Ditylenchus (3.33), Belenolaimus (13.33) and Heterodera (13.33) recorded the lowest densities. Though Kachia LGA had the highest diversity of genera (19) (Table 2), it also gave the lowest population density (870) of genera per $100 \mathrm{ml}$ of soil. But the overall 
average density per $100 \mathrm{ml}$ of soil for all location is 916.66 (Table 3).

The frequency of occurrence also indicated Scutellonema and Aphelenchoides to be the most occurring genera in Jaba LGA, which is significantly higher than all species except Rotylenchus, (Fig. 2). In Kachia LGA however, Meloidogyne species was the most occurring genus and was significantly higher than all species (Fig. 3). Kagarko LGA showed Scutellonema and Pratylenchus to be the most occurring genera and were statistically similar, but significantly higher than all genera (Fig. 4). Meloidogyne species however was significantly higher among the remaining genera. Bulus et al. (2017); Abdulsalam et al. (2017); Jibrin et al. (2013) reported Scutellonema, Pratylenchus and Meloidogyne species among the frequently encountered genera in soils of northern Nigeria under different crop cultivation. Thakur and Shamar (2015) also listed Meloidogyne among the most occurring nematodes under ginger cultivation. Also Koshy et al. (2005) reported Meloidogyne as the most economically important nematode in ginger production. Meloidogyne species is economically important because it causes gall formation and root rots of the underground rhizomes (Okorocha et al., 2014).
Percentage similarities indicates that when two locations are compared, Kachia and Kagarko LGA(s) gave the highest percent similarities but was not significantly higher than when Jaba is compared with Kachia and Jaba compared to Kagarko (Fig. 5). However, when the three locations were compared together, it recorded a significantly lower percent similarity than any two locations compared (Fig. 5).

Longidorus and Xiphinema are known to be virus vectors, their occurrence in high number may be associated with some viruses affecting ginger in the region. Abraham et al. (2020) reported the occurrence of an important virus disease associated with ginger in Kaduna state. This means, further studies may reveal other viruses likely to be vectored by nematodes.

Table 3 : Average Population densities of the plant-parasitic nematodes association with ginger in the surveyed Local Government Area(s)

\begin{tabular}{ccccc}
\hline & \multicolumn{2}{c}{ Population/100 $\mathbf{~ m l ~ o f ~ s o i l ~}$} & & \\
\hline Location & Jaba & Kachia & Kagarko & All locations \\
\hline Plant parasitic Nem. & $\mathbf{N}=\mathbf{1 2}$ & $\mathbf{N = 1 6}$ & $\mathbf{N 1 4}$ & $\mathbf{N}=\mathbf{4 2}$ \\
Aphelenchus sp. & 120 & 60 & 70 & 83.33 \\
Aphenlenchoides sp. & 60 & 40 & 30 & 43.33 \\
Belenolaimusp. & - & 10 & 30 & 36.33 \\
Criconemoides sp & - & 40 & 70 & 3.33 \\
Ditylenchus sp. & - & 10 & - & 50 \\
Helicotylenchus sp & 60 & 30 & 60 & 46.67 \\
Hemicycliophora sp. & 40 & 70 & 30 & 26.67 \\
Heterodera sp. & - & 40 & - & 23.33 \\
Hoplolaimus sp & - & 80 & - & 110 \\
Longidorus sp. & 20 & 30 & 20 & 26.67 \\
Meloidogyne sp & 100 & 130 & 100 & 93.33 \\
Paratylenchus sp & 60 & 20 & - & 90 \\
Pratylenchus sp & 80 & 30 & 170 & 113.33 \\
Rotylenchulus sp & 110 & 100 & 60 & 40 \\
Scutelonema sp & 150 & 40 & 150 & 40 \\
Tylenchorhynchus sp. & 30 & 60 & 30 & 6.67 \\
Tylenchus sp. & 40 & 30 & 50 & 53.33 \\
Trichodorus sp. & 20 & - & - & 916.66 \\
Xiphinema sp & 60 & 50 & 50 & \\
\hline Total & 950 & 870 & 930 & \\
\hline
\end{tabular}

Where $\mathrm{N}=$ number of samples collected 


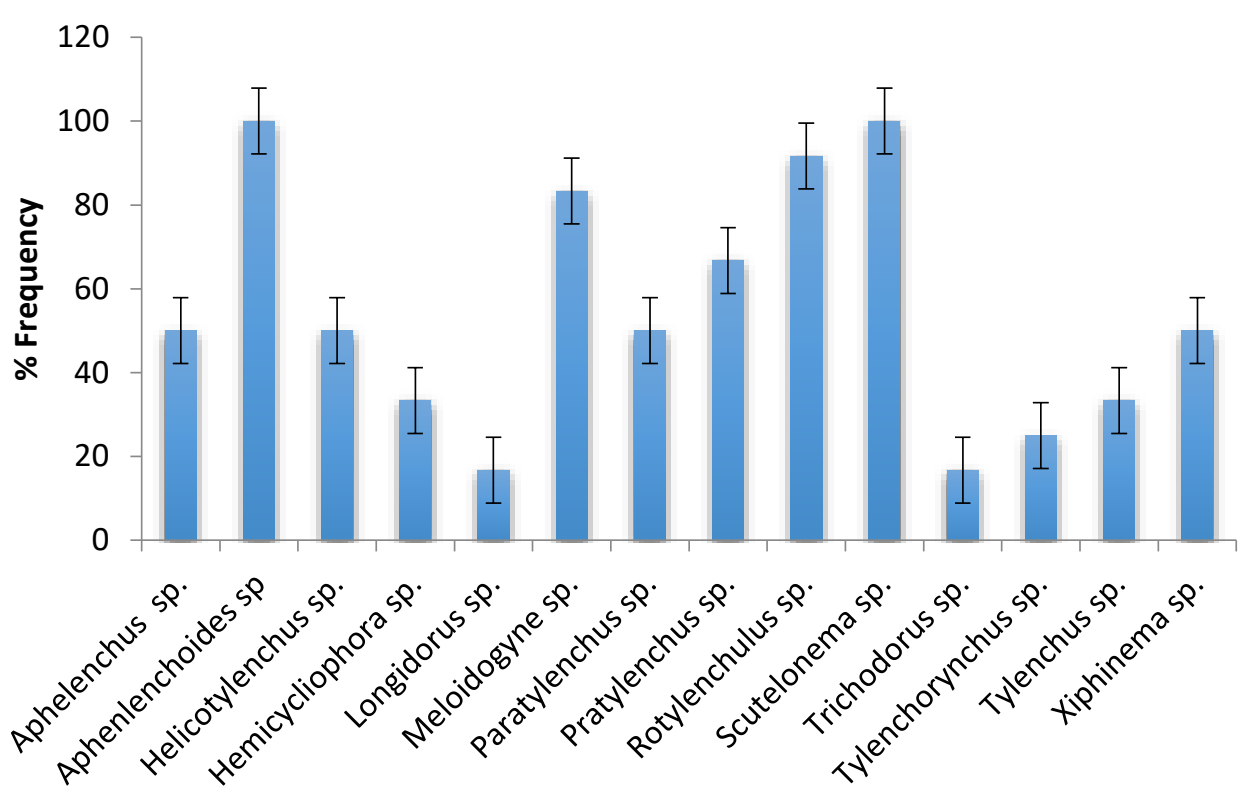

Plant-parasitic nematode genera

Sample size $(\mathrm{N})=12$

Fig. 2: Frequency rating of plant-parasitic nematode genera associated with ginger in Jaba LGA of Kaduna State, Nigeria during the field survey in 2018. Bars indicate standard error of means at 5\% probability level.

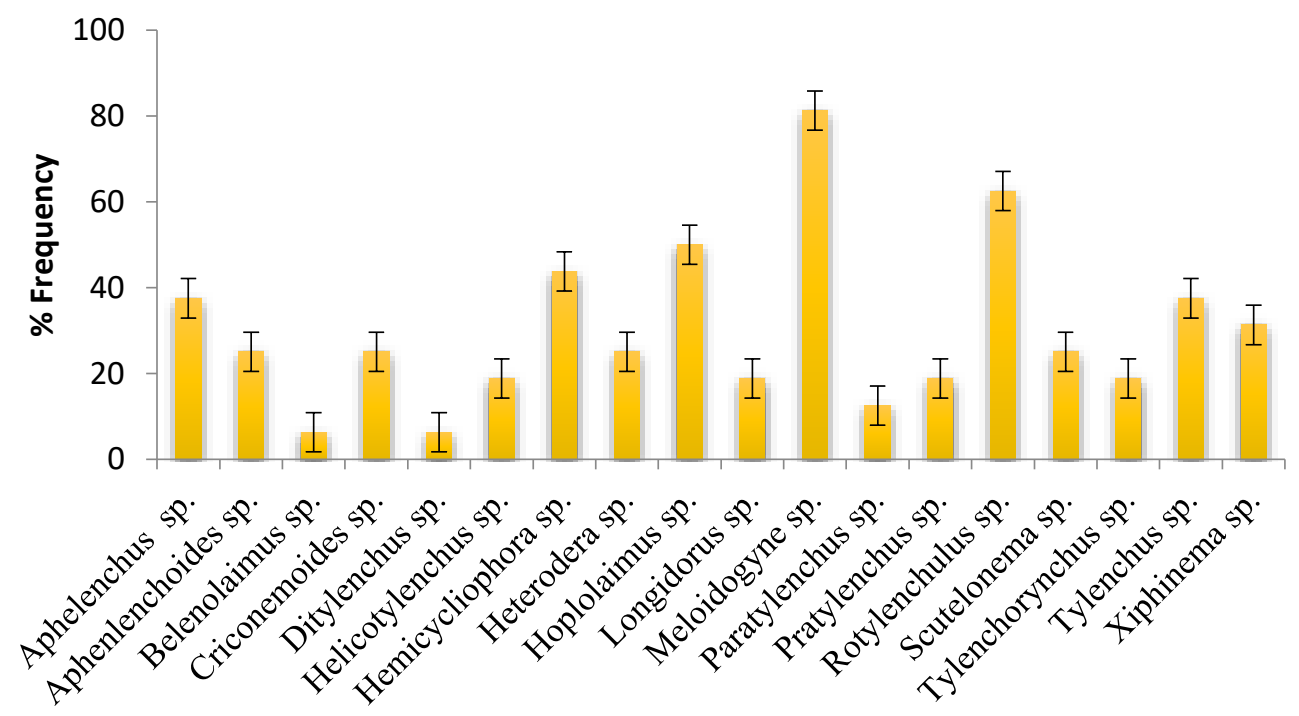

Plant-parasitic nematode genera

Sample size $(\mathrm{N})=16$

Fig. 3: Frequency rating of plant-parasitic nematode genera associated with ginger in Kachia LGA of Kaduna State, Nigeria during the field survey in 2018. Bars indicate standard error of means at 5\% probability level. 


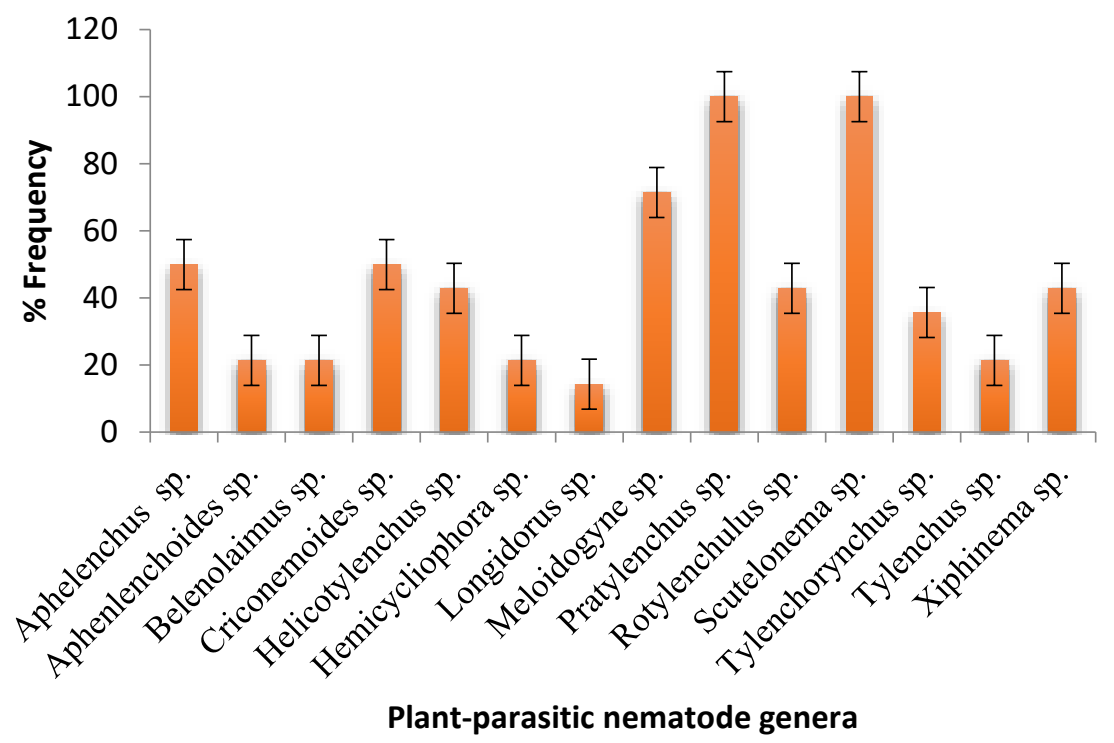

Sample size $(\mathrm{N})=14$

Fig. 4: Frequency rating of plant-parasitic nematode genera associated with ginger in Kagarko LGA of Kaduna State, Nigeria during the field survey in 2018. Bars indicate standard error of means at 5\% probability level.

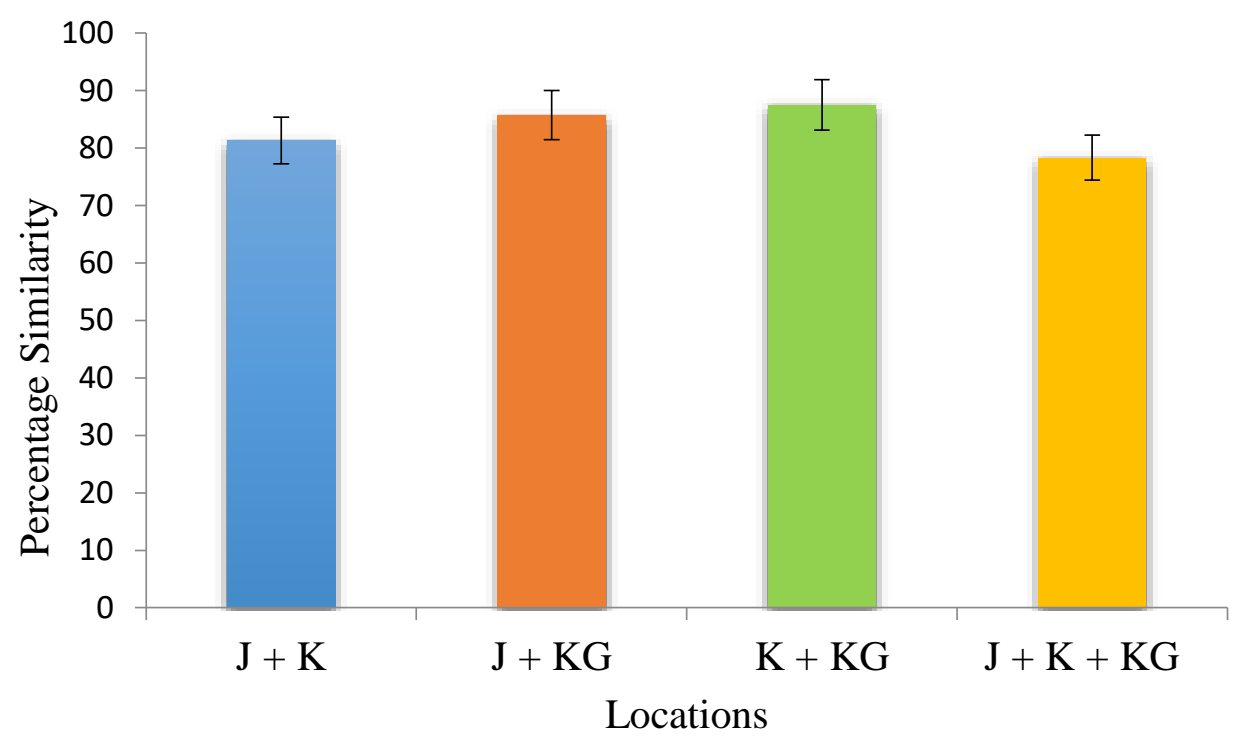

Fig. 5: Similarity (\%) of Plant-parasitic nematodes genera recovered among ginger fields in Jaba (J), Kachia (K) and Kagarko (KG) LGAs of Kaduna State. Bars indicates standard error of means at $5 \%$ probability level.

\section{CONCLUSION}

This finding reveals high diversity of plant-parasitic nematodes associated with ginger in Kaduna state. Perhaps this is a key factor resulting to low yield of ginger in the region, since plantparasitic nematodes causes damage to crops directly and in a complex with other pathogens. To the best of our knowledge, this is the first report of the diversity of plant-parasitic nematodes associated with ginger and first report of
Scutellonema sp occurring in high number under ginger cultivation in Nigeria. Further research should focus on the most occurring genera to establish the population thresholds capable of causing economic yield loss. Awareness on nematodes problems and management should also be created among farmers. 


\section{ACKNOWLEDGEMENTS}

The authors are sincerely grateful to Mr. Donald Iyorchi of Nematology unit, Department of Crop Protection, Ahmadu Bello University Zaria, for his assistance technically in the course of this research.

\section{Conflict of interest}

Authors whose names are listed in this paper hereby certify that they have no conflict of interest.

\section{REFERENCES}

Abdulsalam, S., Chindo, P.S., Agbenin, N.O., Onu, I., Bulus. J. and Nuradeen, M. (2017). Survey of Plant-parasitic Nematodes associated with eggplant (Solanum melongena L.) in Kaduna and Kano states, Nigeria. FUW Journal of Agriculture and Life Sciences 1(1):91-97

Abraham, P., Banwo, O.O., Kashina, B.D., and Alegbejo, M.D., (2020). Occurrence, distribution and alternative hosts of Wheat streak mosaic virus infecting ginger in Kaduna State, Nigeria. Journal of Agriculture and Rural Development in the Tropics and Subtropics, 121 (1): 127-133. DOI:10.17170/kobra-202005281300.

Asumugha, G.N. (2000). Internal marketing and export of ginger in Nigeria: Critical issues and suggestions for support mechanism In: N. Nakatani and K. Komaki (Eds), Potential of root crops for food and industrial resources," in Proceedings12th Symposium of International Society for Tropical Root Crops (ISTRC), Tsukuba, Japan, 10-16 Sept. 2000, pp. 420-423.

Bernard, A. (2008). Diseases, pest and other factors limiting ginger (Zingiber officinale Roscoe) production in River State. Agricultural Product Development Strategy Workshop. Uptonville Foundation under the aegis of Rivers State Sustainable Development Agency (RSSDA). Retrieved from http://uptonvilleoginstu.org/ginger.litm.

Bulus, J., Aminu, A.S., Chindo, P.S. Namakka, A. and Abdulsalam, S. (2017). Distribution and Population densities of plant-parasitic nematodes under irrigated vegetable cultivation in Galma Fadama, Zaria Kaduna state Nigeria. FUW Journal of Agriculture and Life Sciences. 1(1):71-77

Coyne, D. L., Nicol, J.M. and Claudius-Cole, B. (2007). Practical Plant Nematology: A Field and Laboratory Guide. SPIPM, International Institute of Tropical Agriculture (IITA), Cotonou, Benin. 82 pp.

Doncaster, C.C. (1962). A counting dish for nematodes. Nematologia, 7: 334-336.

Duniya, I. B. (2003). An assessment of the marketing perspectives, in the development and implementation, of Kaduna State-owned agro-allied projects: A case study of Kachia food company limited. MSc Thesis, Department of Business Administration, Ahmadu Bello University Zaria, Nigeria. 98 pp.

FAOSTAT. (2017).

http://www.fao.org/faostat/en/\#data/
Fikre, T. \& Kifle, A. (2013). Ginger (Zingiber officinale Roscoe) production, postharvest handling, processing and marketing: a comprehensive extension package manual. Hawassa, Ethiopia, 139 p.

Food and Agricultural Organization (FAO) (2009) "Production quantity of ginger in the world from 1961- 2009. Available www.fao.gingerproduction," pp. $21-26$.

Hodda, M., Banks, N. and Singh, S. (2012). Nematode Threats in NAQS (Northern Australia Quarantine Strategy). Australia. CSIRO, 92Pp

Ibedu, M.A., Unamma, R.P.A., Njoku, B.O and Okorocha, E.A. (1990). Evaluation of ginger for intercropping with soybean, pigeon pea cowpea and egusi. Proceedings of the 4th Annual Farming Systems Res. and Ext. Workshop in S. Eastern Nigeria, Umudike, 21-24 Jan., 66-72pp

Jibrin, M.O., Lawal, H.M. and Chindo, P.S. (2013). Influence of cover crops and tillage systems on nematode population in a maize cover crop intercrop. Archives of Phytopathology and Plant Protection. 47(6):703-710

Kaur, D.J. and Sharma, N.K. (1988). Occurrence and pathogenicity of Meloidogyne arenaria on ginger. Indian Phytopatjology 41: 467-468.

Koshy, P.K., Eapen, S.J. and Pandey, R. (2005). Nematode parasites of spices, condiments and medicinal plants. In: Plant Parasitic Nematodes in Subtropical and Tropical Agriculture (eds) M. Luc, R.A. Sikora and J. Bridge. CAB International Institute of Parasitology, U.K Pp 751-791

Mai, W.F. and Mullin, P. G. (1996). Plant-parasitic nematodes: a pictorial key to genera Cornell University Press, Ithaca, NY.

Makhnotra A.K. (1994). Studies on the nematodes associated with ginger (Zingiber officinale Roscoe). M. Sc. Thesis. University of Horticulture and Forestry, Solan (Nauni) HP.

Mazza, M. (2015). Ginger (Zingiber officinale Roscoe) production practices in Abia State, Nigeria," International Journal of Applied Research and Technology, vol. 4, 36-43pp

Meenu, G. and Jebasingh, T. (2019). Diseases of Ginger Licensee IntechOpen. 24Pp.DOI: http://dx.doi.org/10.5772/intechopen.88839

Nicol, J., Turner, D., Coyne, L., den Nijs, L., Hockland, S., Maafi, Z. (2011) Current nematode threats to world agriculture. In: Jones J, Gheysen G, Fenoll C, editors. Genomics and Molecular Genetics of Plant-Nematode Interactions. Berlin: Springer Science Business Media; pp. 21-43. DOI 10.1007/978-94-007-0434-3_2

Nmadu, J.N. and Marcus, P.L. (2013). Efficiency of Ginger Production in selected local government areas of Kaduna state, Nigeria. International Journal of food and Agricultural Economics. (1):39-52pp.

Norton, D.C. (1989). Abiotic factors and plant-parasitic 
nematode community. Journal of Nematology 21: 299-307pp.

Ojiako, D.M., N.C. Ibe, and I.C. Onweme, (2007) "Towards increased production and export of ginger in Nigeria," in Proceedings on the First National Ginger Workshop. Oct. 17 21,

Okorocha, E.O.A., Ogbuji, R.O., Onyenobi, F.I. and Okorocha, C.G. (2014) Relationship between root-knot nematode Meloidogyne javanica inoculum densities and ginger (Zingiber officinale Roscoe). Scholars Academic Journal of Bioscience 2(11):809-812

Paret, M.L., Cabos, R., Kratky, B.A. and Alvarez, A.M. (2010) Effect of plant essential oils on Ralstonia solanacearum race 4 and bacterial wilt of edible ginger. Plant Disease. 94:521-527

Sasser, J., Freckman, D.A. (1987) world perspective on nematology: The role of the society. In: Veech J, Dickson D, editors. Vistas on Nematology; Society of Nematologists, Inc.: Hyattsville, MD pp.7-14

Sawa, B.E. (2017). The Leading Ginger Producing Countries in the World. http://www.worldatlas.com/articles/the-leadingginger-producing-countries-in-the-world.html;
Sharma, B.R., Dutta, S., Roy. S., Debnath, A. and Roy, M.D. (2010). The effect of soil physicochemical properties on rhizome rot and wilt disease complex incidence of ginger under hill agro climatic region of West Bengal. Journal of Plant Pathology 26:198-202

Singh, S., and Singh-Dhillon, S. (2015). Socio-Economic Analysis of Ginger Crop in Himachal Pradesh. Indian Journal of Hill Farming 28(1), 35-42

Thakur, N. and Sharma, G.C. (2015). Status of Plant-parasitic Nematodes in Ginger Fields of Himachal Prdesh. International Journal of Science, Environment and Technology 4(4):976-979

USAID-NEXTT (2017). Model feasibility study and business plan for ginger processing to oleoresin- an industrywide study report- Final Report. USAID-NEXTT (Nigeria Expanded Trade and Transport) Romis Consultants Ltd., Lagos, Nigeria. $83 \mathrm{Pp}$. 